\title{
Demethylation of methionine and keratin damage in human hair
}

\author{
Kamila Borowczyk ${ }^{1,2} \cdot$ Joanna Suliburska $\cdot$ Hieronim Jakubowski ${ }^{1,4}(\mathbb{C}$
}

Received: 1 August 2017 / Accepted: 20 February 2018 / Published online: 26 February 2018

(c) The Author(s) 2018. This article is an open access publication

\begin{abstract}
Growing human head hair contains a history of keratin and provides a unique model for studies of protein damage. Here, we examined mechanism of homocysteine (Hcy) accumulation and keratin damage in human hair. We found that the content of Hcy-keratin increased along the hair fiber, with levels 5-10-fold higher levels in older sections at the hair's tip than in younger sections at hair's base. The accumulation of Hcy led to a complete loss of keratin solubility in sodium dodecyl sulfate. The increase in Hcy-keratin was accompanied by a decrease in methionine-keratin. Levels of Hcy-keratin were correlated with hair copper and iron in older hair. These relationships were recapitulated in model experiments in vitro, in which Hcy generation from Met exhibited a similar dependence on copper or iron. Taken together, these findings suggest that Hcy-keratin accumulation is due to copper/iron-catalyzed demethylation of methionine residues and contributes to keratin damage in human hair.
\end{abstract}

Keywords Hair keratin damage $\cdot$ Homocysteine $\cdot$ Methionine demethylation $\cdot$ Copper $\cdot$ Iron

$\begin{array}{ll}\text { Abbreviations } & \\ \text { DTT } & \begin{array}{l}\text { Dithiothreitol } \\ \text { Homocysteine }\end{array} \\ \text { Hcy } & \text { High performance liquid chromatography } \\ \text { Hcy-protein } & \begin{array}{l}\text { Hcy linked to a protein via an amide } \\ \text { (peptide or isopeptide) bond }\end{array} \\ N \text {-Hcy-protein } & \begin{array}{l}\text { Hcy linked to a protein via an isopeptide } \\ \text { bond }\end{array} \\ \text { S-Hcy-protein } & \begin{array}{l}\text { Hcy linked to a protein via a disulfide } \\ \text { bond }\end{array} \\ \text { Met } & \begin{array}{l}\text { Methionine } \\ \text { No }\end{array} \\ \text { NDS } & \text { Sodic oxide } \\ \end{array}$

Handling Editor: E. I. Closs.

Hieronim Jakubowski

jakubows@rutgers.edu

1 Department of Microbiology, Biochemistry and Molecular Genetics, Rutgers-New Jersey Medical School, International Center for Public Health, 225 Warren Street, Newark, NJ 07103, USA

2 Department of Environmental Chemistry, University of Łódź, 90-236 Łódź, Poland

3 Department of Human Nutrition and Hygiene, Poznań University of Life Sciences, 60-632 Poznań, Poland

4 Department of Biochemistry and Biotechnology, Poznań University of Life Sciences, 60-632 Poznań, Poland

\section{Introduction}

Homocysteine (Hcy) is a universal intermediate in the metabolism of two major sulfur-containing amino acids methionine (Met) and cysteine. While Met and cysteine (Cys) are canonical coded amino acids that are incorporated into proteins by the ribosomal biosynthetic apparatus, Hcy is not (Jakubowski 2017). However, although Hcy is a non-coded amino acid, proteins carry Hcy residues linked via an isopeptide bond to lysine (Lys) residues ( $\mathrm{N}$-Hcyprotein) (Jakubowski 1999, 2002; Sikora et al. 2014) or via a disulfide bond to cysteine residues ( $S$-Hcy-protein) (Lim et al. 2003; Jacovina et al. 2009). Proteins can also carry Hcy bound by a peptide bond than can be formed translationally by a nitric oxide-dependent mechanism (Jakubowski 2000a, b, 2001, 2017) or post-translationally by metal-dependent demethylation of a protein methionine residue (Mozziconacci et al. 2013). However, although about a dozen individual proteins that contain Hcy N-linked to lysine residues or S-linked to cysteine residues have been identified in vivo in humans or animals (Jakubowski 2013), proteins that carry Hcy bound by a peptide bond have not yet been identified.

Human head hair provides a unique model to address mechanisms of protein aging and damage. Because hair fibers grow at a relatively uniform rate of $1 \mathrm{~cm} /$ month (Nissimov et al. 2007), long hair provide a history of keratin from about a month at their base to several years at their tip. Long 
human hair is known to undergo damage, e.g. generating unsightly splitting ends, but the underlying mechanism is not fully understood. In the present work we have examined a hypothesis that the damage that accumulates in growing human hair is caused by the demethylation of keratin Met residues to Hcy.

\section{Materials and methods}

\section{Reagents}

L-Hcy-thiolactone $\cdot \mathrm{HCl}$, D,L-Hcy, L-methionine, $N$-acetyl-Lcysteine (NAC), horse spleen ferritin, dithiothreitol (DTT), tris-(2-carboxyethyl)phosphine (TCEP), o-phthaldialdehyde (OPA), monosodium phosphate, $\mathrm{NaOH}$, sodium citrate, $\mathrm{NaCl}, \mathrm{CuCl}_{2}, \mathrm{FeCl}_{2}, \mathrm{FeCl}_{3}$, vitamin $\mathrm{C}$, sodium dodecyl sulfate (SDS), chloroform, methanol, $\mathrm{HCl}$, trichloroacetic acid, were purchased from Sigma-Aldrich. Suprapure nitric acid, $65 \%$ and perchloric acid, $60 \%$ were from Merck. Reagents were prepared in MiliQ purified water.

\section{Human hair}

Unaltered head hair was obtained from healthy individuals (females, $n=51,0.5-84$ years old; males, $n=30$, $1.25-68$ years old) recruited from the Poznan population. Shed hair was collected during regular daily combing. Their base was identified by the presence of the hair bulb and only those hairs with the bulb were used in experiments. A 1- or 3 -cm segment of the hair shaft ( $2 \mathrm{mg}$ hair from 15 to 30 individual hairs) was used to quantify Hcy content. The age of a hair segment, estimated from its distance from the scalp, assuming an average hair growth rate of $1 \mathrm{~cm} / \mathrm{month}$ (Nissimov et al. 2007), is indicated in figures. The terms "young hair" and "old hair" or "aged hair" define segments of long hair at their base (close to the scalp) and at the tip, respectively.

\section{Sample preparation for hair S-Hcy-keratin and Hcy-keratin assays}

Samples were prepared by a modification of previously described procedures as described below. The inter-assay and intra-assay variabilities for the quantification of various forms of Hcy were 7.3 and 11.5\% (Jakubowski 2002, 2008, 2016).

\section{S-Hcy-keratin}

To liberate Hcy from $S$-Hcy-keratin, hair $(\sim 2 \mathrm{mg})$ were treated in a $0.5 \mathrm{~mL}$ Eppendorf polyethylene tube with a hot solution containing $50 \mathrm{mM} \mathrm{Na}_{2} \mathrm{HPO}_{4}, 20 \mathrm{mM} \mathrm{NaOH}$,
$25 \mathrm{mM}$ DTT, $1 \%$ SDS $\left(200 \mu \mathrm{L}, 65^{\circ} \mathrm{C}, 1 \mathrm{~h}\right)$. The extract was collected by centrifugation, hair were similarly extracted with a fresh solution the second time, and the extracts combined $(400 \mu \mathrm{L})$. Control experiments show that this procedure liberates $>95 \%$ Hcy present in hair $S$-Hcy-keratin. The extracts $(40 \mu \mathrm{L})$ were treated with DTT $(4 \mu \mathrm{L}, 0.25 \mathrm{M})$ and $\mathrm{HCl}(4 \mu \mathrm{L}, 12 \mathrm{~N})$ on a heat block at $100{ }^{\circ} \mathrm{C}$ for $30 \mathrm{~min}$ to convert the liberated Hcy to Hcy-thiolactone, which was then quantified by HPLC (Jakubowski 2016). Authentic Hcy was similarly processed as a standard for $S$-Hcy assays.

Hair pellets after extraction were saved for SDS-insoluble $\mathrm{N}$-Hcy-keratin quantification.

\section{SDS-soluble Hcy-keratin}

Extracts ( $300 \mu \mathrm{L}$ ) of SDS-soluble Hcy-keratin were supplemented with $34 \mu \mathrm{L} 100 \%$ trichloroacetic acid to precipitate keratin. Protein precipitates were collected by centrifugation, transferred to 1-mL Wheaton Gold Band ampoules, and hydrolyzed in $6 \mathrm{~N} \mathrm{HCl}, 50 \mathrm{mM}$ DTT $\left(110 \mu \mathrm{L}, 120^{\circ} \mathrm{C}, 1 \mathrm{~h}\right)$. The hydrolysates were lyophilized on Labconco CentriVap ( $40 \mathrm{~min}, 70{ }^{\circ} \mathrm{C}$ ), dissolved in $10 \mu \mathrm{L}$ water, purified by twodimensional TLC, and analyzed by HPLC.

\section{SDS-insoluble Hcy-keratin}

Hair pellets containing SDS-insoluble Hcy-keratin were transferred to 1-mL Wheaton Gold Band ampoules and hydrolyzed in $6 \mathrm{~N} \mathrm{HCl}, 50 \mathrm{mM}$ DTT $\left(110 \mu \mathrm{L}, 120^{\circ} \mathrm{C}, 1 \mathrm{~h}\right)$. The hydrolysates were lyophilized on a Labconco CentriVap (40 min, $70^{\circ} \mathrm{C}$ ), dissolved in $10 \mu \mathrm{L}$ water, purified by twodimensional TLC, and analyzed by HPLC.

\section{Total Hcy-keratin}

The term "total Hcy-keratin' refers to the content of all keratin-bound Hcy that is solubilized by acid hydrolysis (i.e., Hcy-keratin $+S$-Hcy-keratin). Hair $(\sim 2 \mathrm{mg})$ were hydrolyzed in 1-mL Wheaton Gold Band ampoules containing $6 \mathrm{~N}$ $\mathrm{HCl}, 50 \mathrm{mM}$ DTT $\left(100 \mu \mathrm{L}, 120{ }^{\circ} \mathrm{C}, 1 \mathrm{~h}\right)$. The hydrolysates were lyophilized using a Labconco CentriVap, dissolved in $100 \mu \mathrm{L} 0.5 \mathrm{M} \mathrm{K}_{2} \mathrm{HPO}_{4}$ on ice, and Hcy-thiolactone was purified by two-dimensional TLC. Alternatively, in some experiments Hcy-thiolactone was purified by a 5-min extraction of ice-cold chloroform/methanol (2:1, v/v, $400 \mu \mathrm{L})$. Organic layer containing Hcy-thiolactone (bottom), separated by a 1-min microcentrifugation at $4{ }^{\circ} \mathrm{C}$, was collected and reextracted with $150 \mu \mathrm{L} 0.1 \mathrm{~N} \mathrm{HCl}$. Aqueous layer containing Hcy-thiolactone (top) was dried on a Labconco CentriVap (40 min, $70{ }^{\circ} \mathrm{C}$ ), dissolved in $100 \mu \mathrm{L}$ deionized water, and analyzed by HPLC.

Horse spleen ferritin, containing $0.49 \mathrm{~mol} \mathrm{~N}$-Hcy/mol protein, was processed in parallel as a standard for $N$-Hcy 
(Jakubowski 2008, 2016). These procedures quantitatively liberate Hcy from $N$-Hcy-protein and convert the liberated Hcy to Hcy-thiolactone, which is then quantified by HPLC (Jakubowski 2002, 2008, 2016).

\section{HPLC, detection, and quantification}

Quantification of Hcy-thiolactone generated from $N$-Hcy-keratin and/or $S$-Hcy-keratin was carried out by as previously described (Chwatko and Jakubowski 2005; Jakubowski 2008, 2016). Briefly, a Beckman-Coulter System Gold Nouveau HPLC instrumentation with a manual injector (7725i Rheodyne, with $0.1 \mathrm{~mL}$ loop) and a Jasco 1520 fluorescence detector were used. Chromatograms were analyzed using a Gold Nouveau chromatography workstation software for Windows. Samples were injected onto a cation-exchange poly-sulfoethyl aspartamide column $(35 \times 2 \mathrm{~mm}, 5 \mu \mathrm{m}, 300 \AA)$ (PolyLC, Inc.), eluted isocratically with $30 \mathrm{mM} \mathrm{NaCl}, 10 \mathrm{mM}$ sodium phosphate buffer (pH 6.6) at a flow rate $0.6 \mathrm{~mL} / \mathrm{min}$. The effluent was mixed in a three-way tee with $2.5 \mathrm{mM}$ OPA in $0.25 \mathrm{M}$ $\mathrm{NaOH}$, delivered at a flow rate $0.3 \mathrm{~mL} / \mathrm{min}$, the mixture passed through a reaction coil (Teflon tubing, $0.3 \mathrm{~mm}$ I.D. $\times 3 \mathrm{~m}$ ), and the fluorescence at $480 \mathrm{~nm}$ was recorded (excitation $370 \mathrm{~nm}$ ). Hcy-thiolactone eluted at $3 \mathrm{~min}$ and each run was completed in 4 min.

\section{Met-keratin and Hcy-keratin assays}

Hair ( $10 \mathrm{mg})$ were hydrolyzed in 1-mL Wheaton Gold Band ampoules containing $6 \mathrm{~N} \mathrm{HCl}\left(100 \mu \mathrm{L}, 120{ }^{\circ} \mathrm{C}\right.$, $1 \mathrm{~h})$. The hydrolysates were dried out, dissolved in $50 \mu \mathrm{L}$ $0.2 \mathrm{M}$ sodium phosphate buffer ( $\mathrm{pH} 7.4)$, reduced with 2 $\mu \mathrm{L} 0.25 \mathrm{M}$ TCEP for $10 \mathrm{~min}$, and supplemented with 10 $\mu \mathrm{L} 0.5 \mathrm{M}$ NAC. Met and Hcy liberated from hair keratin were quantified by HPLC as previously described (Borowczyk et al. 2016). Briefly, a Hewlett-Packard (Waldbronn, Germany) 1100 Series system, controlled by HP ChemStation software, containing quaternary pump, auto-sampler, temperature control, vacuum degasser, and 1260 Series FL detector was used. Samples were injected on a reversedphase PRP-1 column $(150 \times 4.6 \mathrm{~mm}, 5 \mu \mathrm{m}$; Hamilton, Energy Way, Reno, NV, USA) eluted at a flow rate $1 \mathrm{~mL} /$ min, $25{ }^{\circ} \mathrm{C}$, with $0.01 \mathrm{M}$ OPA, $0.1 \mathrm{M} \mathrm{L}-1 \mathrm{NaOH}$ (A) and acetonitrile (B) as follows: $0-8 \mathrm{~min}, 14-25 \%$ (B); 8-12 min, 25\% (B), 12-14 min, 25-14\% (B). Met and Hcy were identified by co-elution with the authentic standards, monitored by fluorescence from 0 to $7.2 \mathrm{~min}$, exc. $348 \mathrm{~nm}$, em. $438 \mathrm{~nm}$ for Met, and from 7.2 to $14 \mathrm{~min}$, ex. $370 \mathrm{~nm}$, em. $480 \mathrm{~nm}$ for Hcy. Elution times for Met and Hcy were 6.2 and $9.8 \mathrm{~min}$, respectively.

\section{Iron and copper assays}

Hair samples were mineralized with 65\% nitric acid (Merck) in a microwave oven (Mars 5 Digestion Microwave System, CEM Corporation). Iron and copper were quantified by flame atomic absorption spectrometry using a Zeiss AAS-3 spectrometer with deuterium background correction as previously described (Suliburska 2011). The accuracy of the assay was $94 \%$ for iron and $102 \%$ for copper as verified by certified reference materials (Human Hair NCS DC73347a, LGC Standards).

\section{Demethylation of free Met to Hcy}

Model reactions were carried out at $37{ }^{\circ} \mathrm{C}$ in Na-citrate buffer, $\mathrm{pH}$ 6.0, containing Met, copper or iron chloride salts, and vitamin $\mathrm{C}$ in a final volume of $400 \mu \mathrm{L}$ under conditions specified in figure legends. Hcy generated from methionine was assayed by the conversion to Hcy-thiolactone, which was quantified by HPLC as previously described (Jakubowski 2016). Briefly, $5 \mu \mathrm{L}$ aliquots of reaction mixtures were treated with $5 \mu \mathrm{L}$ DTT, $10 \mu \mathrm{L}$ water, and $10 \mu \mathrm{L}$ $3 \mathrm{~N} \mathrm{HCl}$ at $100^{\circ} \mathrm{C}$ for $20 \mathrm{~min}$. The assay mixtures were dried on a Labconco CentriVap, dissolved in $100 \mu \mathrm{L}$ water, and analyzed by cation exchange HPLC. Authentic Hcy samples were similarly processed as standards. The inter-assay and intra-assay variabilities were 4.7 and $6.8 \%$ for Hcy, and 1.0 and $3.4 \%$ for Met, respectively.

\section{Statistical analysis}

The results are reported as mean \pm standard deviation. Comparisons between two groups are analyzed by using twosided Student's test. Relationships between Hcy-keratin and hair age or metal content were fitted to exponential equations and analyzed by linear regression. The level of statistical significance was set to $P<0.05$. Analyses were carried out by using Sigma Plot software.

\section{Results}

\section{Hair contain Hcy bound by amide/peptide and disulfide bonds}

To quantify Hcy, human hair samples $(n=76)$ were acidhydrolyzed to liberate any Hcy that might be bound to keratin by amide/peptide or disulfide bonds. We found that each hair sample contained Hcy, which varied 14-fold between individuals (from 37 to $510 \mathrm{pmol} / \mathrm{mg}$ ) and did not depend on individual's age or gender (Fig. 1a). Mean \pm SD Hcy values were similar for females and males, $176 \pm 85(n=38)$ and $228 \pm 133 \mathrm{pmol} / \mathrm{mg}(n=21)$, respectively (Table 1$)$. 
Free Hcy is unlikely to occur in human hair because it is frequently washed or otherwise exposed to water. Indeed, control experiments showed that of the $322 \pm 134$ pmol Hcy/ mg present in samples of human hair $(n=4)$, only about $1 \%$ $(4.4 \pm 1.2 \mathrm{pmol} \mathrm{Hcy} / \mathrm{mg})$ was solubilized by the treatment with $20 \mathrm{mM} \mathrm{K}_{2} \mathrm{HPO}_{4}$. Because keratin is the major component of hair, accounting for $95 \%$ by weight (Robbins 2012), these findings suggest that Hcy is a natural component of human hair keratin.

\section{Total Hcy-keratin content increases along the hair fiber}

Hair fibers grow at a relatively uniform rate of $1 \mathrm{~cm} /$ month. Thus, long hairs provide an aging history of keratin from about a month at hair's base to several years at its tip. To determine how Hcy dynamics change during the hair growth, we quantified total Hcy-keratin content in short and long hair. We found that total Hcy-keratin was significantly elevated at the tips of long, i.e. old, hair fibers relative to the short, i.e. young, hair fibers. However, total Hcy-keratin level exhibited inter-individual variability that was independent of individual's age (Fig. 1b) and gender (Table 1).

We then quantified total Hcy-keratin content along human hair fibers as long as $50 \mathrm{~cm}$, corresponding to hair's age of 50 months at the tip. We found that in long hair total Hcy-keratin increased continuously along hair fibers, reaching 5-10-fold higher levels at their tips (i.e. in old hair), compared with the levels at their base close to the scalp (i.e. in young hair), both in females (Fig. 2a) and males (Fig. 2b).
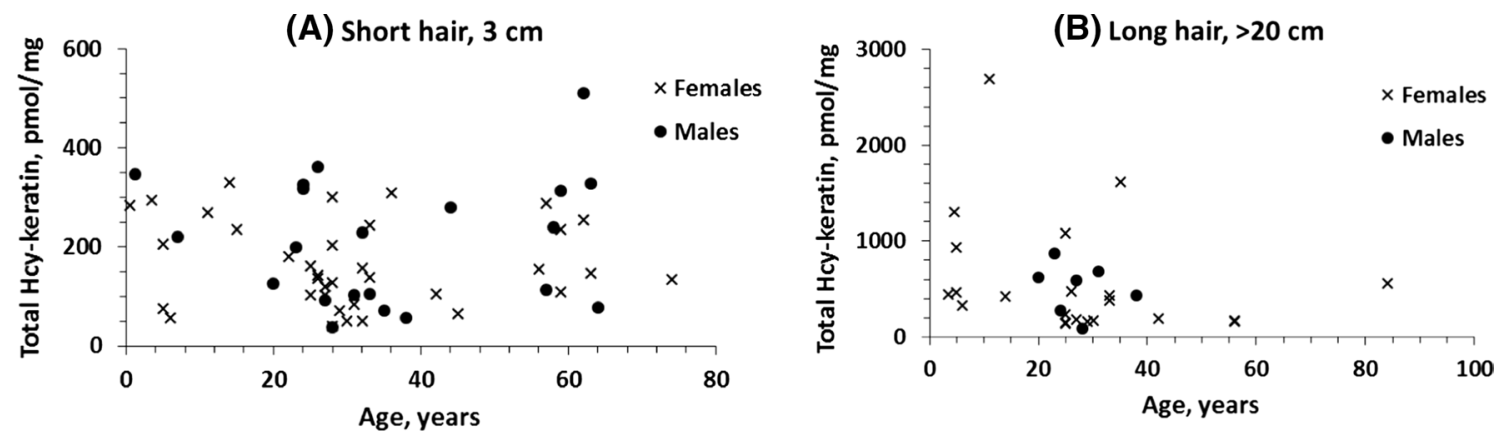

Fig. 1 Relationships between human hair Hcy-keratin and the donor's age. a Short hair $(3 \mathrm{~cm})$ and $\mathbf{b}$ long hair $(>20 \mathrm{~cm})$

Table 1 Total Hcy-keratin content increases at tips of long human hair

\begin{tabular}{llll}
\hline Gender $(n)$ & \multicolumn{2}{l}{ Mean total Hcy-keratin $\pm \mathrm{SD}, \mathrm{pmol} / \mathrm{mg}$ hair } \\
\cline { 2 - 4 } & Short hair, $3 \mathrm{~cm}(n)$ & Long hair, $>20 \mathrm{~cm}(n)$ & $\begin{array}{l}P \text { value, long } \\
\text { vs. short hair }\end{array}$ \\
\hline Female & $176 \pm 85(n=38)$ & $542 \pm 615(n=21)$ & 0.002 \\
Male & $228 \pm 133(n=21)$ & $508 \pm 288(7)$ & 0.010 \\
\hline
\end{tabular}
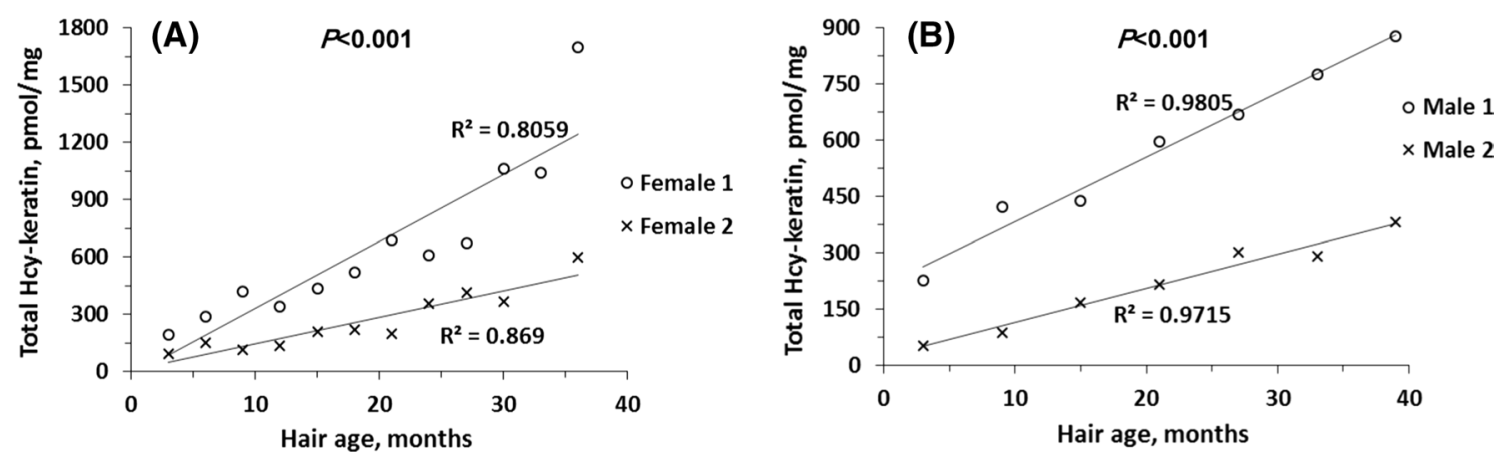

Fig. 2 Relationships between hair total Hcy-keratin levels and hair age in individual human subjects. a Females; b males 


\section{Increase in Hcy during hair growth is due to the accumulation of Hcy-keratin but not S-Hcy-keratin}

The accumulation of Hcy in hair keratin (Fig. 2) can be due to $S$-Hcy-keratin, Hcy-keratin, or both. The S-linked Hcy can be liberated from $S$-Hcy-keratin by the treatment with a reducing agent such as DTT, while Hcy bound via an amide or peptide bond can be liberated from Hcy-keratin only by acid hydrolysis. To determine which form of Hcy accumulates during hair growth, we quantified $S$-Hcy-keratin and Hcy-keratin at the base of hair fibers, i.e. in young hair, and at the tip of hair fibers, i.e. in old hair, for each individual.

We found that Hcy-keratin and $S$-Hcy-keratin were present in human hair, with the levels unaffected by individual's gender, but varied in opposite directions with the hair's age. In young hair (0-3 months old) there was less Hcy-keratin than $S$-Hcy-keratin (82-88 vs. $178-181 \mathrm{pmol} / \mathrm{mg}$, or 30 vs. $70 \%$ ) (Table 2). In aged hair (24-60 months old) Hcy-keratin levels increased to about $500 \mathrm{pmol} / \mathrm{mg}$, while $S$-Hcy-keratin decreased to about $60-80 \mathrm{pmol} / \mathrm{mg}$ (Table 2). Thus, in old hair there was much more Hcy-keratin (90\%) and much less S-Hcy-keratin (10\%).

\section{Hcy accumulation renders human hair keratin SDS-insoluble}

Because Hcy accumulation in a protein alters or damages the protein's structure and affects its solubility (Jakubowski 2013), we examined keratin solubility (Jakubowski 1999) at hair's base, i.e. in young hair, and at hair's tip, i.e. in old hair. To determine which Hcy modification might be responsible for keratin damage, we examined how the solubility of keratin is related to its $S$-Hcy-keratin and Hcy-keratin content.

We found that keratin solubility was negatively correlated with Hcy-keratin and hair's age (Fig. 3a, b). In young hair, about $50 \%$ of Hcy-keratin was SDS-soluble and $50 \%$ was SDS-insoluble (Fig. 3b). Remarkably, levels of SDS-insoluble Hcy-keratin increased (Fig. 3a), while SDS-soluble Hcy-keratin decreased (Fig. 3b) with hair's age. In aged hair sections, essentially all Hcy-keratin became SDS-insoluble (Fig. 3a, b). SDS-PAGE analysis showed that SDS-soluble protein of $45 \mathrm{kDa}$ molecular weight, corresponding to type I keratin (Langbein et al. 1999) that could be extracted from young hair sections was essentially absent in aged hair sections (Fig. 4).

$S$-Hcy-keratin in young hair $(300 \mathrm{pmol} / \mathrm{mg})($ Fig. 3c) accounted for about $80 \%$ of total Hcy-keratin (Fig. 3d). However, there was a gradual decline in $S$-Hcy-keratin levels with the hair section age to about $50 \mathrm{pmol} / \mathrm{mg}$, or about $10 \%$ of total Hcy-keratin at 50 months. Taken together these findings suggest that the loss of keratin solubility is caused by the accumulation of Hcy-keratin rather than the decrease of $S$-Hcy-keratin.

\section{Hcy-keratin accumulation is accompanied by a decrease in Met-keratin in human hair}

Keratin is known to contain Met residues, which are a likely source of Hcy residues. Although hair is metabolically inactive, it is possible that keratin Met residues are demethylated to Hcy chemically. Thus, if Met-keratin is a chemical precursor of Hcy-keratin, one can predict that Met-keratin levels will be decreased in aged hair. To examine this prediction, we quantified Met-keratin levels at the tip of hair (i.e., in old hair) and at its base (i.e., in young hair) for each individual. We found that Met-keratin levels were significantly reduced in old hair compared with young hair $(20.8 \pm 3.3$ vs. $25.1 \pm 3.9 \mu \mathrm{g} / \mathrm{mg}, P=0.0113$ ), whereas Hcy-keratin levels were elevated $(457.6 \pm 322.7$ vs. $74.9 \pm 95.7 \mathrm{pmol} /$ $\mathrm{mg}, P=0.0012$ ) (Table 3).

\section{Hcy-keratin accumulation in human hair is positively correlated with copper and iron contents}

Free Met is known to be demethylated to Hcy in the presence of cuprous copper $\left(\mathrm{Cu}^{+}\right)$(Lieberman and Kunishi 1965) or ferrous iron $\left(\mathrm{Fe}^{2+}\right)$ (Baggott and Tamura 2007). This raises a possibility that the accumulation of Hcy-keratin in growing

Table 2 Hcy-keratin and $S$-Hcy-keratin levels in young and old human hair

\begin{tabular}{llllll}
\hline Gender $(n)$ & $\begin{array}{l}\text { Hair segment age, } \\
\text { months }\end{array}$ & $\begin{array}{l}\text { Hcy-keratin } \\
(\mathrm{pmol} / \mathrm{mg})\end{array}$ & $\begin{array}{l}S \text {-Hcy-keratin } \\
\text { pmol/mg }\end{array}$ & Hcy/(Hcy $+S$-Hcy) & $\begin{array}{c}\text { Fraction of SDS- } \\
\text { insoluble Hcy- } \\
\text { keratin }\end{array}$ \\
\hline Female (12) & $0-3$ & $88 \pm 27$ & $178 \pm 112$ & $0.35 \pm 0.14$ & $0.62 \pm 0.16$ \\
Female (12) & $25-60$ & $493 \pm 491$ & $82 \pm 39$ & $0.78 \pm 0.14$ & $0.91 \pm 0.09$ \\
$P$ value, old vs. young hair & & 0.0096 & 0.0135 & 0.0000001 & 0.00005 \\
Male (7) & $0-3$ & $82 \pm 41$ & $181 \pm 64$ & $0.31 \pm 0.11$ & $0.51 \pm 0.10$ \\
Male (3) & $24-52$ & $516 \pm 129$ & $62 \pm 14$ & $0.89 \pm 0.02$ & $0.98 \pm 0.03$ \\
$P$ value, old vs. young hair & & 0.00003 & 0.0155 & 0.00001 & 0.00005 \\
\hline
\end{tabular}



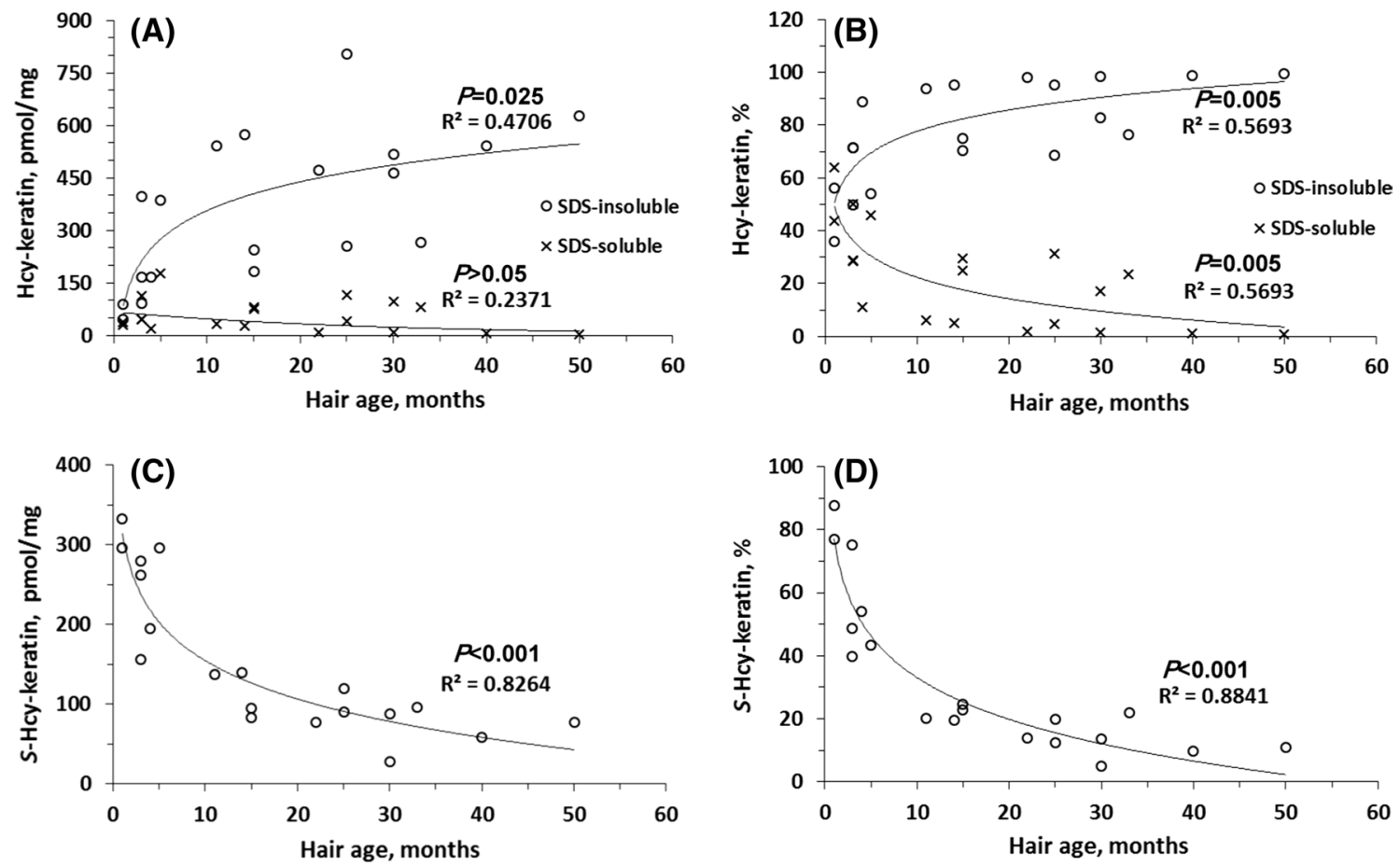

Fig. 3 Relationships between human hair Hcy-keratin and S-Hcykeratin and hair age. a SDS-insoluble and SDS-soluble Hcy-keratin; b relative values of SDS-insoluble and SDS-soluble Hcy-keratin; c $S$-Hcy-keratin; d relative values of $S$-Hcy-keratin. Hair sec-

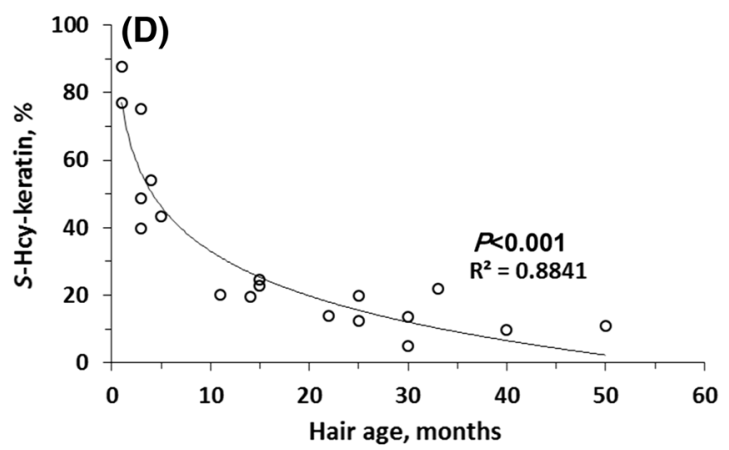

tions $(1-3 \mathrm{~cm})$ of indicated age were collected from 5-year-old individuals. Each data point represents a different individual with a different hair age/length $(n=19,52.6 \%$ female)

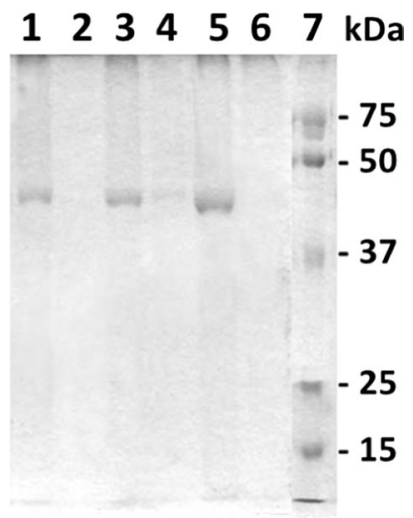

Fig. 4 SDS-PAGE analysis of human hair keratin. Young and old hair were extracted with SDS/DTT solution as described in Materials and Methods. The extracts were analyzed on 10\% SDS-PAGE gels. A keratin band is visible in samples from young hair (0-3 months) of three individuals are shown in lanes 1,3 , and 5. Soluble keratin is essentially absent in old hair (36-50 months) from the same individuals, as shown in lanes 2, 4, and 6. Lane 7 shows molecular weight standards

Table 3 Levels of Met-keratin and Hcy-keratin in young and old hair

\begin{tabular}{lll}
\hline Hair age, months & \multicolumn{2}{l}{ Mean \pm SD } \\
\cline { 2 - 3 } & $\begin{array}{l}\text { Met-keratin }(n=11), \\
\text { nmol/mg }\end{array}$ & $\begin{array}{l}\text { Hcy-keratin } \\
(n=11), \mathrm{pmol} / \\
\mathrm{mg}\end{array}$ \\
\hline $0-3$ & $25.1 \pm 3.9$ & $74.9 \pm 95.7$ \\
$24-51$ & $20.8 \pm 3.3$ & $457.6 \pm 322.7$ \\
$P$ value & 0.0113 & 0.0012 \\
\hline
\end{tabular}

Table 4 Levels of copper and iron in young and old hair

\begin{tabular}{lll}
\hline Hair age, months & \multicolumn{2}{l}{ Mean $\pm \mathrm{SD}$} \\
\cline { 2 - 3 } & Copper $(n=14), \mu \mathrm{g} / \mathrm{g}$ & Iron $(n=14), \mu \mathrm{g} / \mathrm{g}$ \\
\hline $0-3$ & $17.2 \pm 12.4$ & $29.9 \pm 16.3$ \\
$24-51$ & $26.8 \pm 22.9$ & $30.3 \pm 13.2$ \\
$P$ value & 0.21 & 0.79 \\
\hline
\end{tabular}

hair could be due the $\mathrm{Cu} / \mathrm{Fe}$-dependent Met $\rightarrow$ Hcy demethylation reaction.

To determine whether $\mathrm{Cu}$ or $\mathrm{Fe}$ can account for the accumulation of Hcy-keratin in growing hair we examined relationships between copper or iron and Hcy-keratin levels in aged hair. We found that that $\mathrm{Cu}$ and Fe levels were similar

in the old and young hair (Table 4). We also found that there was a significant positive correlation between Hcy-keratin and copper $(P<0.001$, Fig. 5a) but not with iron $(P>0.05$, Fig. 5b) levels in aged hair. Copper explains $69 \%$ of the variation in Hcy-keratin, while iron might explain only $28 \%$. These findings suggest that $\mathrm{Cu}$-dependent and to a lesser 


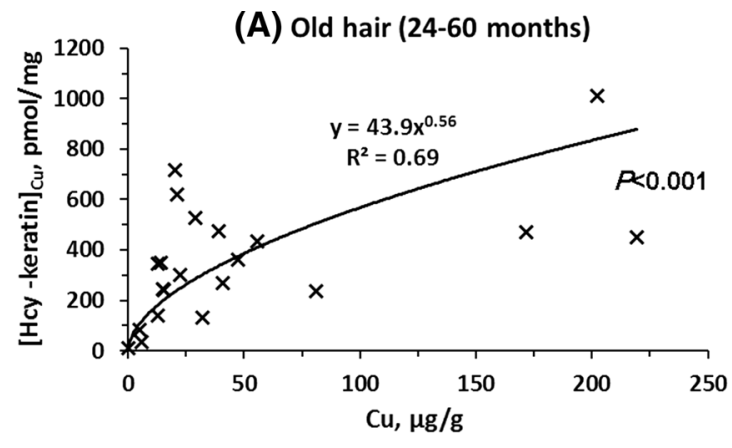

Fig. 5 Relationships between human hair Hcy-keratin and copper (a) or iron (b) levels in 24-60-months-old hair. Contributions of copper to Hcy-keratin levels, [Hcy-keratin $]_{\mathrm{Cu}}$, were calculated according to a formula: $[\text { Hcy-keratin }]_{\mathrm{Cu}}=\{3.5[\mathrm{Cu} / \mathrm{Fe}] /(3.5[\mathrm{Cu} / \mathrm{Fe}]+1)\}[\mathrm{Hcy}-$ keratin $]_{\mathrm{Cu}+\mathrm{Fe}}$, where $[\text { Hcy-keratin }]_{\mathrm{Cu}+\mathrm{Fe}}$ is total Hcy-keratin. Contri-

extent Fe-demethylation of Met-keratin is responsible for the accumulation of Hcy-keratin in aged hair.

\section{Demethylation of free methionine}

The relationships between Hcy-keratin and $\mathrm{Cu}$ or $\mathrm{Fe}$ in aged hair (Fig. 5) suggest that the $\mathrm{Cu}$-dependent generation of Hcy-keratin is more efficient than the Fe-dependent reaction. This prompted us to examine $\mathrm{Cu}$ - and Fe-dependent generation of Hcy from free Met. We found that free Met was de-methylated to Hcy in reaction mixtures containing $\mathrm{CuCl}_{2}$ (Fig. 6a) or $\mathrm{FeCl}_{3}$ (Fig. 6b) in the presence, but not in the absence, of vitamin $\mathrm{C}$. Because vitamin $\mathrm{C}$ serves as a reducing agent that converts $\mathrm{Cu}^{2+}$ and $\mathrm{Fe}^{3+}$ to catalytically active $\mathrm{Cu}^{+}$and $\mathrm{Fe}^{2+}$, respectively, these findings are consistent with the participation of cuprous copper $\left(\mathrm{Cu}^{+}\right)$(Lieberman and Kunishi 1965) or ferrous iron $\left(\mathrm{Fe}^{2+}\right)$ (Baggott and Tamura 2007) in the Met $\rightarrow$ Hcy demethylation reaction. Indeed, the Met $\rightarrow$ Hcy demethylation occurred in reaction mixtures with $\mathrm{FeCl}_{2}$ in the absence of vitamin $\mathrm{C}$ (Fig. 6b).

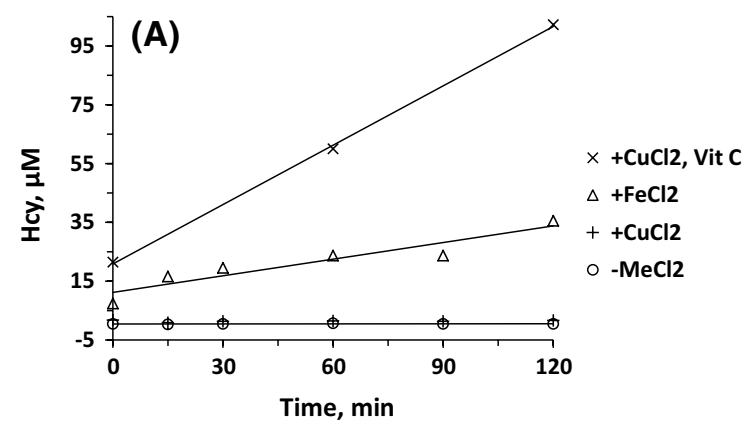

Fig. 6 Time courses of copper- or iron-dependent demethylation of free Met to Hcy. Assays were carried out at $37^{\circ} \mathrm{C}$ for $0-2 \mathrm{~h}$ in reaction mixtures $(400 \mu \mathrm{L})$ containing $5 \mathrm{mM}$ Met, $5 \mathrm{mM}$ Na-citrate, $\mathrm{pH}$ 6.0 , and the following additions at $5 \mathrm{mM}$ each: $\mathbf{a} \mathrm{FeCl}_{2}$ (open trian-

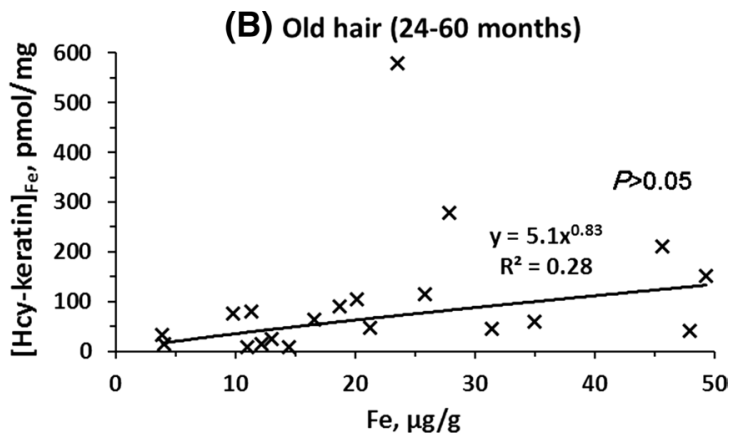

butions of iron to Hcy-keratin levels, [Hcy-keratin $]_{\mathrm{Fe}}$, were calculated according to a formula: $[\text { Hcy-keratin }]_{\mathrm{Fe}}=[\text { Hcy-keratin }]_{\mathrm{Cu}+\mathrm{Fe}}-[$ Hcykeratin $]_{\mathrm{Cu}}$. The factor 3.5 is a ratio of $\mathrm{Cu}$-dependent to $\mathrm{Fe}$-dependent demethylation of Met to Hcy in model reactions shown in Figs. 6 and 7

The rate of the Met demethylation reaction with $\mathrm{Cu} / \mathrm{vita}-$ min $\mathrm{C}$ was 3.5-fold faster than with $\mathrm{Fe} /$ vitamin C. There was no Met $\rightarrow$ Hcy conversion in the absence of $\mathrm{Cu}$ or $\mathrm{Fe}$, vitamin $\mathrm{C}$, or in the presence of either $\mathrm{CuCl}_{2}$ (Fig. 6a) or $\mathrm{FeCl}_{3}$ (Fig. 6b) alone.

We also found that the Met $\rightarrow$ Hcy demethylation reaction was dependent on concentrations of free Met (Fig. 7a), vitamin $\mathrm{C}$ (Fig. 7b), as well as $\mathrm{CuCl}_{2}$ and $\mathrm{FeCl}_{3}$ in the presence of vitamin C (Fig. 7c). The Met $\rightarrow$ Hcy demethylation reaction was up to 3.5 -fold more efficient with copper/vitamin $\mathrm{C}$ than with iron/vitamin $\mathrm{C}$ over a wide range of vitamin C (Fig. 7b) and metal concentrations (Fig. 7c). Remarkably, the relationships between Hcy generation and $\mathrm{Cu}$ or Fe levels in these in vitro experiments recapitulate the relationship between Hcy-keratin and $\mathrm{Cu}$ or $\mathrm{Fe}$ in aged human hair (Fig. 5). Similar dependencies on $\mathrm{Cu} / \mathrm{Fe}$ levels observed for Hcy-keratin in humans and for Hcy in vitro suggest that $\mathrm{Cu} / \mathrm{Fe}$-dependent demethylation of keratin Met residues is responsible for the accumulation of Hcy-keratin in growing human hair.

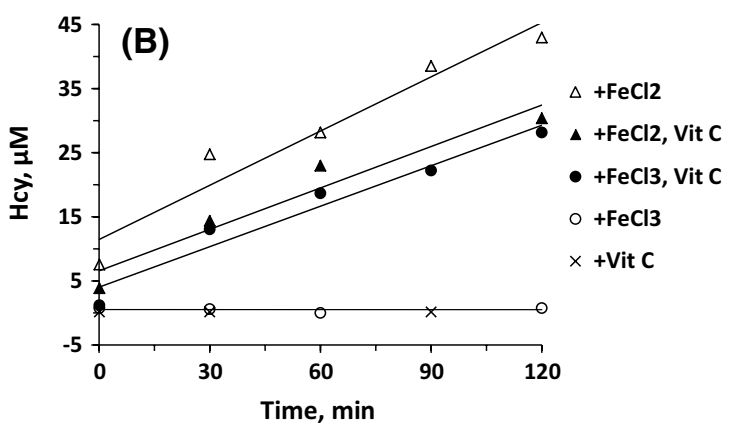

gle), $\mathrm{FeCl}_{2}$ and vitamin $\mathrm{C}$ (filled triangle), $\mathrm{FeCl}_{3}$ (open circle), $\mathrm{FeCl}_{3}$ and vitamin $\mathrm{C}$ (filled circle), or vitamin $\mathrm{C}$ (times symbol); $\mathbf{b} \mathrm{CuCl}_{2}$ (plus), $\mathrm{CuCl}_{2}$ and vitamin $\mathrm{C}$ (times symbol), $\mathrm{FeCl}_{2}$ (open triangle), no additions (open circle) 

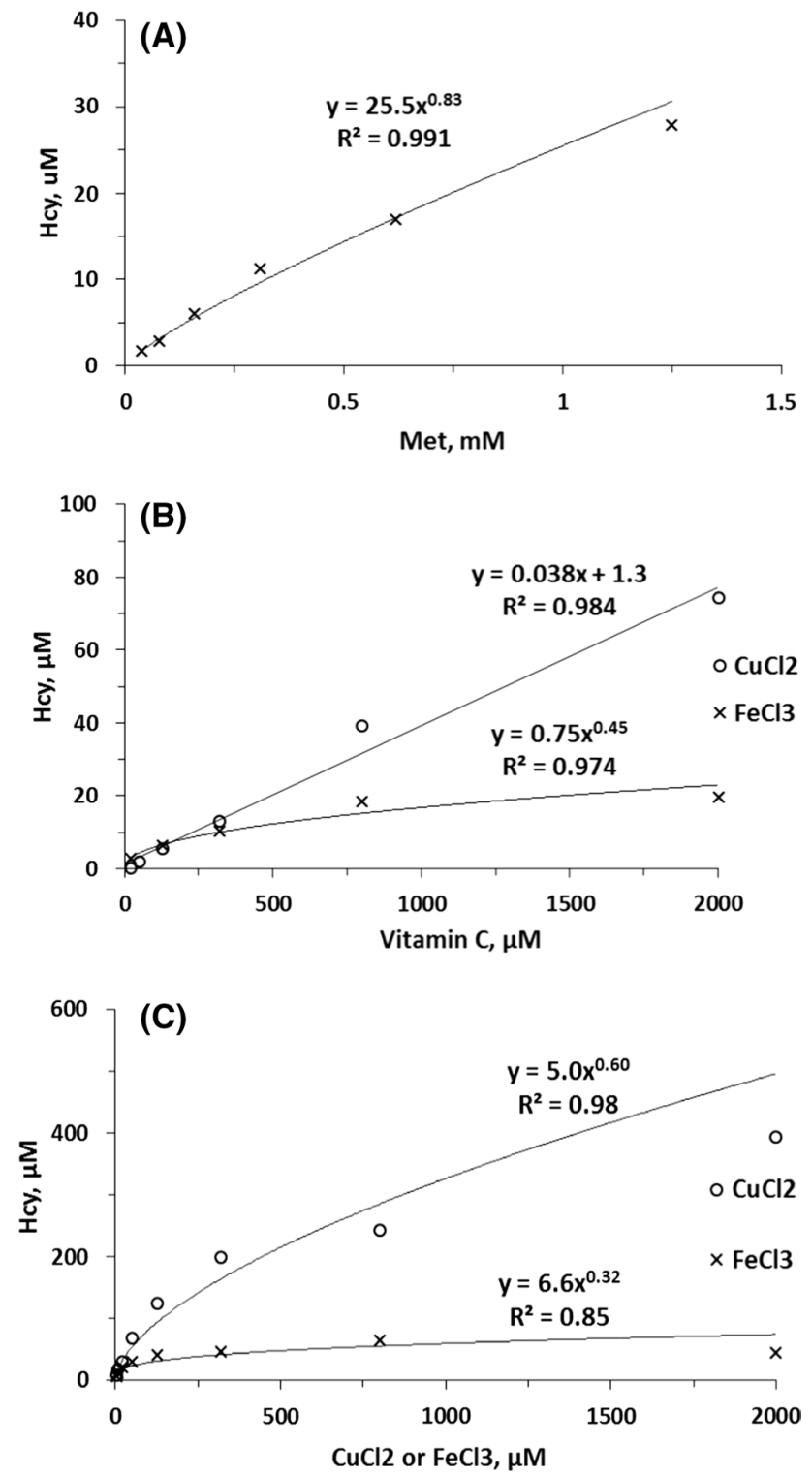

Fig. 7 Copper- or iron-dependent demethylation of free Met to Hcy. Assays were carried out at $37{ }^{\circ} \mathrm{C}$ for $2 \mathrm{~h}$ in $10 \mathrm{mM} \mathrm{Na}$-citrate buffer, $\mathrm{pH} 6.0(400 \mu \mathrm{L})$ containing the following additions. a $0.04-1.25 \mathrm{mM}$ Met and $2.5 \mathrm{mM} \mathrm{FeCl}_{2}$ (times symbol); b $0.02-2 \mathrm{mM}$ vitamin $\mathrm{C}$ and $1 \mathrm{mM} \mathrm{CuCl}_{2}$ (open circle) or $\mathrm{FeCl}_{3}$ (times symbol). c 3.3-2000 $\mu \mathrm{M}$ $\mathrm{CuCl}_{2}$ (open circle) or $\mathrm{FeCl}_{3}$ (times symbol), $5 \mathrm{mM}$ Met, and $5 \mathrm{mM}$ vitamin $\mathrm{C}$

\section{Discussion}

The present work shows that older sections of growing human hair accumulate Hcy-keratin with a concomitant reduction of Met-keratin levels. Our data are consistent with the mechanism of Hcy-keratin accumulation involving $\mathrm{Cu}-$ and $\mathrm{Fe}$-dependent demethylation of Met residues in keratin. We also show that this process is associated with hair keratin damage, manifested by a loss of solubility in SDS solutions. To the best of our knowledge this is the first example of
$\mathrm{Cu} / \mathrm{Fe}$-dependent protein Met $\rightarrow$ Hcy conversion associated with protein damage in humans.

Previous work has shown that proteins carry Hcy residues linked via an amide bond (Hcy-protein) (Sikora et al. 2014) or a disulfide bond (S-Hcy-protein) (Lim et al. 2003; Jacovina et al. 2009). Three mechanisms can account for the generation of Hcy-proteins: (1) modification of protein lysine residues by Hcy-thiolactone (Jakubowski 1999); (2) a nitric oxide (NO)-mediated mechanism affording $S$-NO-Hcy, which is a substrate for aminoacylation of tRNA ${ }^{\text {Met }}$ by methionyl-tRNA synthetase, forming $S$-NO-Hcy-tRNA ${ }^{\mathrm{Met}}$, which in turn participates in protein biosynthesis on ribosomes by delivering $S$-NO-Hcy at positions normally occupied by Met (Jakubowski 2000a, b, 2001, 2017); (3) iron-catalyzed de-methylation of protein Met residues to Hcy (Mozziconacci et al. 2013). $S$-Hcy-proteins are generated in a red-ox mechanism involving free Hcy (Jakubowski 1999, 2000a, b; Lim et al. 2003). About three dozen of individual proteins that contain Hcy linked via an amide or a disulfide bond have been studied in vitro (Jakubowski 2013) and some of them, including albumin (Glowacki and Jakubowski 2004), fibrinogen (Sikora et al. 2014), collagen (Perla-Kajan et al. 2016), transthyretin (Lim et al. 2003), annexin A-2 (Jacovina et al. 2009), dynein (Akchiche et al. 2012), and major urinary protein (Jakubowski 2016), have been identified in vivo in humans or animals. The present study adds human hair keratin to the list of Hcy-containing proteins that have been identified in vivo.

Although in metabolically active tissues Hcy can be incorporated into proteins via amide or peptide bonds by pathways mediated by Hcy-thiolactone or $S$-NO-Hcy, respectively, both dependent on methionyl-tRNA synthetase (Jakubowski 2011, 2012, 2017), these pathways cannot be operational in metabolically inactive tissues such as hair. Thus, another mechanism must be responsible for Hcykeratin accumulation in human hair. Our data suggest that $\mathrm{Cu}$ - and Fe-catalyzed demethylation of keratin Met residues to Hcy is involved. This mechanism is supported by the following evidence.

First, we show that Hcy-keratin accumulation is accompanied by a concomitant decrease in Met-keratin (Table 3); this is consistent with Met-keratin being a precursor of Hcykeratin. Second, there are significant correlations between Hcy-keratin and $\mathrm{Cu} / \mathrm{Fe}$ levels, with $\mathrm{Cu}$ and $\mathrm{Fe}$ accounting for 69 and 28\%, respectively, of the inter-individual variation in Hcy-keratin in aged hair (Fig. 5). Third, the relationships between Hcy-keratin and $\mathrm{Cu}$ or Fe levels in human hair were recapitulated in in vitro $\mathrm{Cu} / \mathrm{Fe}$-dependent Met demethylation experiments (Fig. 7c).

Copper and iron occur in human hair (Chojnacka et al. 2005; Suliburska 2011) and the hair is constantly exposed to reducing conditions promoting demethylation of Met-keratin to Hcy-keratin. The reduced cuprous $\mathrm{Cu}^{+}$and ferrous 
$\mathrm{Fe}^{2+}$ cations required for the Met $\rightarrow$ Hcy demethylation reaction are most likely generated by the exposure of hair during cosmetic treatments with plant extracts or shampoos and conditioners containing vitamin $\mathrm{C}$ and other antioxidants (Fernandez et al. 2012). In fact, juice squeezed from cereal grasses has been shown to reduce ferric to ferrous iron (Pornprasertpol et al. 2015). Our findings that levels of $S$-Hcy-keratin, i.e., Hcy linked to keratin via a disulfide bond, were gradually decreasing with hair's age (Fig. 3), is consistent with exposures to reducing agents such as ascorbic acid, which would reduce the disulfide-bound Hcy to free Hcy (Park 2001) which is lost during hair washing.

Previous in vitro work with model proteins (Jakubowski 2013) shows that the accumulation of $N$-Hcy-protein alters the protein's structure/function and can lead to the generation of insoluble protein aggregates (Jakubowski 1999) with amyloid-like properties (Paoli et al. 2010). The free Hcy thiol in $N$-Hcy-protein is susceptible to one-electron redox reactions, generating intermediary radicals and/or radial ions (Schoneich 2017). These intermediates can in turn generate protein multimers bound by disulfide bonds (Jakubowski 1999; Perla-Kajan et al. 2007) and other reaction products (Sibrian-Vazquez et al. 2010). Thyil radicals produced from $\mathrm{N}$-Hcy-protein can undergo hydrogen atom transfer generating $\mathrm{C}^{\alpha}$-centered radicals, well-known precursors of protein carbonyls (Sibrian-Vazquez et al. 2010; Schoneich 2017). Indeed, $N$-Hcy-protein is susceptible to further oxidative damage (Glowacki and Jakubowski 2004), which leads to protein aggregation manifested by a loss of solubility (Jakubowski 1999). That these mechanisms are physiologically relevant is supported by findings showing that the accumulation of $\mathrm{N}$-Hcy in motor proteins dynein and kinesin leads to aggregation of these proteins in brains of hyperhomocysteinemic rats (Akchiche et al. 2012).

The present work provides the first example of Hcyrelated protein damage in humans. Specifically, we have shown that in older sections of hair human essentially all Hcy-keratin is SDS-insoluble, in contrast to the young hair sections in which only about half of Hcy-keratin is SDSinsoluble (Fig. 3a, b). Further, SDS-PAGE analysis of hair protein shows that essentially all keratin in older hair sections is SDS-insoluble and cannot be extracted (Fig. 4).

Other amino acid residues can also be damaged during protein aging (Stadtman and Levine 2003). For example, amino acids that absorb UV light, such as cysteine, tryptophan, tyrosine and phenylalanine residues in hair keratin are damaged by sun light (Robbins 2012). However, methionine does not absorb UV light and thus is resistant to sun light damage (Forbes et al. 1962). Thus, our finding that in aged hair sections essentially all Hcy-keratin is SDS-insoluble strongly suggests that $\mathrm{Cu} / \mathrm{Fe}$-dependent demethylation of Met-keratin to Hcy-keratin is responsible for hair keratin damage.
The ultimate proof for the demethylation of methionine residues in keratin would require mass spectroscopy analyses. Unfortunately, because of a complete loss of keratin's solubility in aged sections of human hair (Fig. 4), such analyses cannot be carried out.

In conclusion, our data provide evidence for Hcy-related protein damage in humans and suggest an underlying mechanism. In this mechanism, $\mathrm{Cu}$ - and $\mathrm{Fe}$-dependent demethylation reactions convert Met residues in keratin to Hcy, forming SDS-insoluble Hcy-keratin in human hair. Although additional experiments are required to verify whether this mechanism is widespread and affects other proteins, our results provide a new understanding of protein damage.

Acknowledgements This study was supported in part by grants 2012/07/B/NZ7/01178, 2013/09/B/NZ5/02794, 2013/11/B/NZ1/00091, 2013/09/D/ST5/03909, and 2016/23/B/NZ5/00573 from the National Science Center, Poland.

Author contributions KB performed $S$-Hcy-keratin, Hcy-keratin, and Met-keratin assays; JS quantified copper and iron contents in hair; HJ designed study, supervised experiments, performed Hcy-keratin assays and methionine demethylation experiments, analyzed data, and drafted the paper. All authors reviewed the results and approved the final version of the manuscript.

\section{Compliance with ethical standards}

Conflict of interest The authors declare that they have no conflict of interest.

Ethical approval All procedures performed in studies involving human participants were in accordance with the ethical standards of the institutional and/or national research committee and with the 1964 Helsinki Declaration and its later amendments or comparable ethical standards. The study was approved by the Bioethics Commission at the Poznan University of Medical Sciences (Approval no. 08/11).

Informed consent Written informed consent was obtained from all individuals participating in the study. Written informed consent was also obtained from the parents of all participants under the age of 16 .

Open Access This article is distributed under the terms of the Creative Commons Attribution 4.0 International License (http://creativeco mmons.org/licenses/by/4.0/), which permits unrestricted use, distribution, and reproduction in any medium, provided you give appropriate credit to the original author(s) and the source, provide a link to the Creative Commons license, and indicate if changes were made.

\section{References}

Akchiche N, Bossenmeyer-Pourie C, Kerek R, Martin N, Pourie G, Koziel V, Helle D, Alberto JM, Ortiou S, Camadro JM, Leger T, Gueant JL, Daval JL (2012) Homocysteinylation of neuronal proteins contributes to folate deficiency-associated alterations of differentiation, vesicular transport, and plasticity in hippocampal neuronal cells. FASEB J 26(10):3980-3992 
Baggott JE, Tamura T (2007) Iron-dependent formation of homocysteine from methionine and other thioethers. Eur J Clin Nutr 61(12):1359-1363

Borowczyk K, Chwatko G, Kubalczyk P, Jakubowski H, Kubalska J, Glowacki R (2016) Simultaneous determination of methionine and homocysteine by on-column derivatization with $o$-phtaldialdehyde. Talanta 161:917-924

Chojnacka K, Gorecka H, Chojnacki A, Gorecki H (2005) Interelement interactions in human hair. Environ Toxicol Pharmacol 20(2):368-374

Chwatko G, Jakubowski H (2005) The determination of homocysteinethiolactone in human plasma. Anal Biochem 337(2):271-277

Fernandez E, Martinez-Teipel B, Armengol R, Barba C, Coderch L (2012) Efficacy of antioxidants in human hair. J Photochem Photobiol B 117:146-156

Forbes WF, Rivett DE, Savige WE (1962) Photolysis and photoxidation of amino acids and peptides-VI. The degradation of methionine and homocysteine by various forms of radiation. Photochem Photobiol 1:217-230

Glowacki R, Jakubowski H (2004) Cross-talk between Cys34 and lysine residues in human serum albumin revealed by N-homocysteinylation. J Biol Chem 279(12):10864-10871

Jacovina AT, Deora AB, Ling Q, Broekman MJ, Almeida D, Greenberg CB, Marcus AJ, Smith JD, Hajjar KA (2009) Homocysteine inhibits neoangiogenesis in mice through blockade of annexin A2-dependent fibrinolysis. J Clin Invest 119(11):3384-3394

Jakubowski H (1999) Protein homocysteinylation: possible mechanism underlying pathological consequences of elevated homocysteine levels. FASEB J 13(15):2277-2283

Jakubowski H (2000a) Calcium-dependent human serum homocysteine thiolactone hydrolase. A protective mechanism against protein $N$-homocysteinylation. J Biol Chem 275(6):3957-3962

Jakubowski H (2000b) Translational incorporation of S-nitrosohomocysteine into protein. J Biol Chem 275(29):21813-21816

Jakubowski H (2001) Translational accuracy of aminoacyltRNA synthetases: implications for atherosclerosis. J Nutr 131(11):2983S-2987S

Jakubowski H (2002) Homocysteine is a protein amino acid in humans. Implications for homocysteine-linked disease. J Biol Chem 277(34):30425-30428

Jakubowski H (2008) New method for the determination of protein N-linked homocysteine. Anal Biochem 380(2):257-261

Jakubowski H (2011) Quality control in tRNA charging-editing of homocysteine. Acta Biochim Pol 58(2):149-163

Jakubowski H (2012) Quality control in tRNA charging. Wiley Interdiscip Rev RNA 3(3):295-310

Jakubowski H (2013) Homocysteine in protein structure/function and human disease - chemical biology of homocysteine-containing proteins. Springer, Wien

Jakubowski H (2016) Quantification of urinary S- and N-homocysteinylated protein and homocysteine-thiolactone in mice. Anal Biochem 508:118-123

Jakubowski H (2017) Homocysteine editing, thioester chemistry, coenzyme A, and the origin of coded peptide synthesis dagger. Life (Basel) 7(1):6
Langbein L, Rogers MA, Winter H, Praetzel S, Beckhaus U, Rackwitz HR, Schweizer J (1999) The catalog of human hair keratins. I. Expression of the nine type I members in the hair follicle. J Biol Chem 274(28):19874-19884

Lieberman M, Kunishi AT (1965) Ethylene production from methionine. Biochem J 97(2):449-459

Lim A, Sengupta S, McComb ME, Theberge R, Wilson WG, Costello CE, Jacobsen DW (2003) In vitro and in vivo interactions of homocysteine with human plasma transthyretin. J Biol Chem 278(50):49707-49713

Mozziconacci O, Ji JA, Wang YJ, Schoneich C (2013) Metal-catalyzed oxidation of protein methionine residues in human parathyroid hormone (1-34): formation of homocysteine and a novel methionine-dependent hydrolysis reaction. Mol Pharm 10(2):739-755

Nissimov J, Elchalal U, Bakala H, Brownlee M, Berry E, Phillip M, Milner Y (2007) Method for chronological recording of antigen appearance in human head-hair shafts and its use for monitoring glycation products in diabetes. J Immunol Methods 320(1-2):1-17

Paoli P, Sbrana F, Tiribilli B, Caselli A, Pantera B, Cirri P, De Donatis A, Formigli L, Nosi D, Manao G, Camici G, Ramponi G (2010) Protein N-homocysteinylation induces the formation of toxic amyloid-like protofibrils. J Mol Biol 400(4):889-907

Park JB (2001) Reduction of dehydroascorbic acid by homocysteine. Biochim Biophys Acta 1525(1-2):173-179

Perla-Kajan J, Marczak L, Kajan L, Skowronek P, Twardowski T, Jakubowski H (2007) Modification by homocysteine thiolactone affects redox status of cytochrome C. Biochemistry 46(21):6225-6231

Perla-Kajan J, Utyro O, Rusek M, Malinowska A, Sitkiewicz E, Jakubowski H (2016) N-Homocysteinylation impairs collagen cross-linking in cystathionine beta-synthase-deficient mice: a novel mechanism of connective tissue abnormalities. FASEB J 30(11):3810-3821

Pornprasertpol A, Sereemaspun A, Sooklert K, Satirapipatkul C, Sukrong S (2015) Anticancer activity of selected Colocasia gigantia fractions. J Med Assoc Thai 98(Suppl 1):S98-S106

Robbins CR (2012) Chemical and physical behavior of human hair. Springer, New York

Schoneich C (2017) Sulfur radical-induced redox modifications in proteins: analysis and mechanistic aspects. Antioxid Redox Signal 26(8):388-405

Sibrian-Vazquez M, Escobedo JO, Lim S, Samoei GK, Strongin RM (2010) Homocystamides promote free-radical and oxidative damage to proteins. Proc Natl Acad Sci USA 107(2):551-554

Sikora M, Marczak L, Kubalska J, Graban A, Jakubowski H (2014) Identification of N-homocysteinylation sites in plasma proteins. Amino Acids 46(1):235-244

Stadtman ER, Levine RL (2003) Free radical-mediated oxidation of free amino acids and amino acid residues in proteins. Amino Acids 25(3-4):207-218

Suliburska J (2011) A comparison of levels of select minerals in scalp hair samples with estimated dietary intakes of these minerals in women of reproductive age. Biol Trace Elem Res 144(1-3):77-85 